
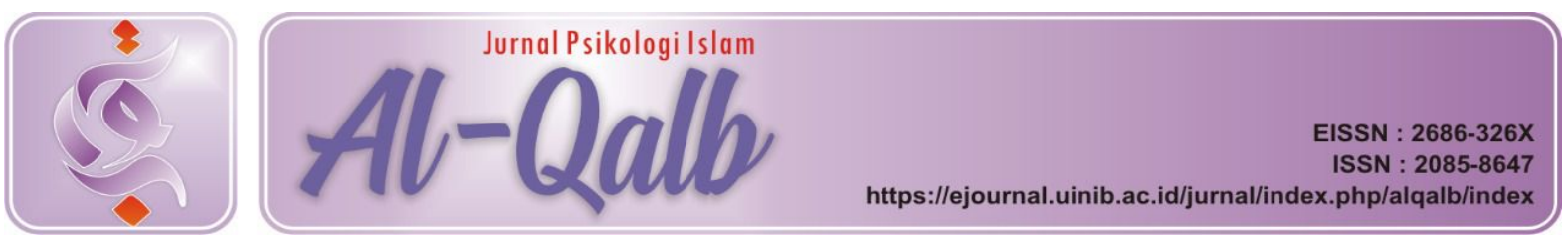

\title{
KEMANDIRIAN PADA USIA LANJUT
}

Received: $12^{\text {th }}$ September 2019; Revised: 07th October 2019; Accepted: $24^{\text {th }}$ October 2019

\section{Sintya Risfi}

UIN Imam Bonjol Padang

Email: risficintya@gmail.com

\section{Hasneli}

UIN Imam Bonjol Padang

Email: HasneliM17@gmail.com

Kata Kunci: Kemandirian, Usia Lanjut

\section{PENDAHULUAN}

Manusia adalah makhluk hidup yang mengalami pertumbuhan dan perkembangan yang kompleks. Semenjak pembuahan
ABSTRAK. Penelitian ini dilatarbelakangi oleh usia lanjut yang memiliki kemandirian dalam dirinya, yang mampu menjalani kehidupan sehari-hari dengan membangun kembali kemandirian dalam dirinya, subjek dalam penelitian ini adalah usia lanjut yang memiliki kemandirian. Tujuan dari penelitian ini adalah untuk mengetahui bagaimana gambaran kemandirian pada usia lanjut dan untuk mengetahui apa saja faktor-faktor yang mempengaruhi kemandirian pada usia lanjut $R$. Pendekatan yang digunakan dalam penelitian ini adalah pendekatan kualitatif dengan model studi kasus. Subjek penelitian terdiri dari 1 orang subjek primer dan 2 orang subjek sekunder. Teknik pengumpulan data dalam penelitian ini melalui observasi, wawancara, dan dokumentasi. Analisi data yang digunakan dalam penelitian ini adalah analisis Miles \& Huberman.

Hasil penelitian terlihat dari gambaran kemandirian pada usia lanjut, dimana kemandirian emosional dapat dilihat bahwa dalam melakukan kegiatan sehari-hari subjek tidak mengeluh kepada orang lain mengenai kegiatan yang dilakukannya. Ketika subjek merasa sedih dan merasakan kekecewaan, ia tidak menceritakannya kepada orang lain, subjek hanya menceritakannya kepada keluarganya saja, kemandirian tingkah laku dapat dilihat bahwa dalam mengambil suatu keputusan subjek mempertimbangkan terlebih dahulu apa yang akan dilakukannya, apakah keputusan diambil baik atau tidak bagi dirinya. Ketika membuat keputusan subjek tidak pernah ragu dengan keputusan yang dibuatnya, seperti dalam mengambil keputusan kalau subjek akan tetap bekerja atau berjualan di pasar walaupun anak-anaknya sudah melarang, karena bagi subjek berjualan dengan mengikuti banyak kegiatan bisa membuat ia merasa bahagia, kemandirian nilai dapat dilihat bahwa dalam memecahkan suatu masalah yang dihadapi, subjek tidak langsung menyelesaikannya sendiri, tetapi subjek mufakat terlebih dahulu dengan suami dan anaknya bagaimana cara menyelesaikan masalah tersebut. Subjek memiliki harapan untuk berhasil, dengan cara menerapka keyakinan bahwa ia akan berhasil dengan cara selalu berusaha. 
masa kanak-kanak, masa remaja, masa dewasa, dan usia lanjut. Pada rentang kehidupan manusia, ada satu periode yang disebut usia tua atau usia lanjut.

Usia tua adalah periode penutup dalam rentang hidup seseorang, yaitu suatu periode di mana seseorang telah beranjak jauh dari periode terdahulu yang lebih menyenangkan, atau beranjak dari waktu yang penuh manfaat.Tahap terakhir dalam rentang kehidupan dibagi menjadi usia lanjut dini, yang berkisar antara usia 60-70 tahun dan usia lanjut tua yang mulai pada usia 70 sampai pada akhir kehidupan seseorang. Menurut standar beberapa kamus yang berarti makin lanjut seseorang dalam periode hidupnya maka telah hilang kejayaan pada masa mudanya (Hurlock, 2002: 380).

Menurut Papalia, 2008: 845 penuaan merujuk kepada tiga kelompok usia lanjut yaitu, usia lanjut muda (young old), usia lanjut tua (old old), dan usia lanjut tertua (oldest old). Secara kronologis, young old secara umum berkisar antara usia 65 sampai 74 tahun, yang biasanya aktif, vital, dan bugar. Old-old berusia antara 75 sampai 84 tahun, dan olddest old berusia 85 tahun ke atas, berkecenderungan lebih besar lemah dan tidak bugar serta memiliki kesulitan dalam mengelola aktivitas keseharian.

Usia lanjut memiliki kekuatan yang jauh berkurang dari yang pernah mereka miliki dan lebih terbatas kemampuannya dalam aktivitas yang mensyaratkan daya tahan atau kemampuan membawa beban berat. Orang dewasa biasanya kehilangan sekitar 10 sampai 20 persen kekuatan mereka ketika mencapai usia 70 tahun, terutama pada otot tubuh bagian bawah. Kekuatan berjalan menurun lebih konsisten sejalan dengan bertambahnya usia, terutama di kalangan perempuan (Papalia, 2008: 862).

Kemandirian adalah kebebasan untuk bertindak, tidak tergantung pada orang lain dan bebas mengatur diri sendiri atau aktivitas seseorang baik individu maupun kelompok dari berbagai kesehatan atau penyakit. Kesehatan lansia perlu mendapat perhatian khusus dengan tetap memelihara dan meningkatkan agar selama mungkin bisa hidup secara produktif sesuai kemampuannya (Wulandari, 2014: 144).

Perkembangan kemandirian merupakan masalah penting sepanjang rentang kehidupan manusia. Perkembangan kemandirian sangat dipengaruhi oleh perubahan-perubahan fisik, yang pada gilirannya dapat memicu terjadinya perubahan emosional, perubahan kognitif yang memberikan pemikiran logis tentang cara berfikir yang mendasari tingkah laku. Kemandirian menuntut suatu kesiapan individu, baik kesiapan fisik maupun emosional untuk mengatur, mengurus dan melakukan aktivitas atas tanggung jawabnya sendiri tanpa banyak menggantungkan diri pada orang lain (Desmita, 2010: 184).

Mandiri mengandung makna bahwa dalam menjalani hajat hidup sehari-hari tidak tergantung kepada orang lain. Bagi usia lanjut kemampuan untuk tetap mandiri adalah sesuatu yang didambakan. Kiranya tidak seorang tuapun yang tidak menginginkan mandiri (Suardiman, 2011: 192). Kemandirian emosional adalah aspek kemandirian yang menyatakan perubahan kedekatan hubungan emosional antar individu, kemandirian tingkah laku adalah suatu kemampuan untuk membuat keputusan-keputusan tanpa tergantung pada orang lain dan melakukakannya secara bertanggung jawab, dan kemandirian nilai adalah kemampuan memaknai seperangkat prinsip tentang benar dan salah, serta tentang apa yang penting dan apa yang tidak penting (Hosnan, 2016: 186).

Berdasarkan dari hasil obseravasi dan wawancara yang penulis peroleh, terlihat bahwa dalam menjalankan kehidupan sehari-harinya $\mathrm{R}$ dapat mengatur kemandirian emosionalnya dengan baik, $\mathrm{R}$ memiliki kesabaran di dalam dirinya, $\mathrm{R}$ tidak pernah mengeluh dengan apapun yang menimpa dirinya, dalam kemandirian tingkah laku, setiap yang dilakukannya $\mathrm{R}$ selalu memikirkan terlebih dahulu apakah yang dilakukannya itu baik atau tidak baik bagi dirinya, dalam kemandirian nilai ketika $\mathrm{R}$ akan memecahkan sesuatu $\mathrm{R}$ tidak 
langsung menyelesaikannya sendiri, tetapi $\mathrm{R}$ menyelesaikannya sesuai dengan ketetapan yang sudah ada.

Keinginan untuk mandiri di dalam diri $\mathrm{R}$ di dorong oleh keinginannya untuk memperoleh kepuasaan batin, $\mathrm{R}$ ingin menunjukkan bahwa dirinya masih bisa berprestasi, mampu mencari uang sendiri, dan masih sanggup melakukan hal-hal yang tidak mungkin lagi bisa dilakukan oleh kebanyakan usia lanjut di sekelilingnya, hal ini dapat menimbulkan perasaan bahwa dirinya berguna dan menimbulkan rasa percaya diri dalam dirinya untuk melakukan banyak kegiatan lainnya.

Berdasarkan fenomena dan wawancara yang penulis lakukan di atas, maka penulis memberikan judul penelitian ini, "Kemandirian pada Usia Lanjut (Studi Kasus di Dusun Koto Malintang Jorong Baso Kenagarian Tabek Panjang Kabupaten Agam)".

\section{TINJAUAN TEORI}

\section{A. Kemandirian}

\section{Pengertian Kemandirian}

Kemandirian atau autonomy adalah kebebasan individu untuk memilih, untuk menjadi kesatuan yang bisa memerintah, menguasai dan menentukan dirinya sendiri. Kemandirian merupakan kemampuan untuk mengendalikan dan mengatur pikiran, perasaan dan tindakan sendiri secara bebas serta berusaha sendiri untuk mengatasi perasaanperasaan malu dan keragu-raguan (Chaplin, 2005: 48).

Mandiri mengandung makna bahwa dalam menjalani hajat hidup sehari-hari tidak tergantung kepada orang lain. Kemandirian merupakan kemampuan untuk mengambil inisiatif, kemampuan mengatasi masalah, dan kemampuan untuk memperoleh kepuasan dari usaha sendiri serta keinginan untuk mengerjakan sesuatu tanpa bantuan dari orang lain (Suardiman, 2011: 193).
Menurut Lindgren (dalam Suardiman, 2011: 193) juga menyatakan bahwa individu yang mandiri adalah individu yang memiliki keteguhan hati tentang siapakah dia dan siapa yang bertanggung jawab atas perilakunya sendiri. Kemandirian berkembang dari ketergantungan yang besar terhadap orang lain menuju kepada semakin besarnya ketergantungan terhadap dirinya sendiri.

Menurut Desmita (2016: 185), kemandirian adalah suatu kondisi dimana seseorang memiliki hasrat bersaing untuk maju demi kebaikan dirinya sendiri dan mampu mengambil keputusan dan inisiatif untuk mengatasi masalah yang dihadapi.

Berdasarkan pemaparan di atas dapat dipahami bahwa kemandirian adalah kemampuan individu mengendalikan dan mengatur pikiran, serta perasaan untuk mengambil inisiatif dalam mengatasi masalah, dan kemampuan untuk memperoleh kepuasan dari usaha sendiri tanpa bantuan dari orang lain.

\section{Aspek-aspek Kemandirian}

Menurut Hosnan (2016: 186), aspek-aspek kemandirian ada tiga, yaitu:

a. Kemandirian emosional, yakni aspek kemandirian yang menyatakan perubahan kedekatan hubungan emosional antar individu.

b. Kemandirian tingkah laku, yakni suatu kemampuan untuk membuat keputusan-keputusan tanpa tergantung pada orang lain dan melakukakannya secara bertanggung jawab.

c. Kemandirian nilai, yakni kemampuan memaknai seperangkat prinsip tentang benar dan salah, serta tentang apa yang penting dan apa yang tidak penting. 
Sementara itu, Steinberg (dalam Desmita, 2010: 186), juga membagi aspek-aspek kemandirian menjadi 3 bentuk, yaitu:

a. Kemandirian emosional, yakni aspek kemandirian yang menyatakan perubahan kedekatan hubungan emosional antar individu.

b. Kemandirian tingkah laku, yakni suatu kemampuan untuk membuat keputusan-keputusan tanpa tergantung pada orang lain dan melakukakannya secara bertanggung jawab.

d. Kemandirian nilai, yakni kemampuan memaknai seperangkat prinsip tentang benar dan salah, serta tentang apa yang penting dan apa yang tidak penting.

Senada dengan pendapat Steinberg (dalam Arumsari, 2016: 43-44), membagi aspek-aspek kemandirian menjadi 3 bentuk, yaitu:

\section{a. Emotional autonomy}

(kemandirian emosi), merupakan aspek kemandirian yang berhubungan dengan perubahan kedekatan atau keterikatan hubungan emosional individu, terutama dengan keluarga. Steinberg (dalam Sukardi, 2013: 338) juga menjelaskan kemandirian emosional adalah kemandirian yang merujuk pada pengertian yang dikembangkan mengenai individuasi dan melepaskan diri atas ketergantungan dalam pemenuhan kebutuhankebutuhan dasar dari orang tua. Kemandirian emosional seseorang dapat dilihat dari beberapa indikator, diantaranya sebagai berikut:

1) Tidak mengadu kepada keluarga ketika mengalami kesedihan, kekecewaan, kekhawatiran, atau ketika ia sedang membutuhkan bantuan.

2) Tidak lagi memandang keluarganya sebagai orang yang mengetahui segalagalanya atau menguasai segala-galanya.

3) Seringkali mempunyai energi emosional yang besar dalam rangka menyelesaikan hubungan-hubungan di luar keluarganya, dan dalam kenyataannya individu merasa lebih dekat dengan teman-temannya daripada keluarganya sendiri.

\section{b. Behavioral} autonomy (kemandirian tingkah laku), merupakan aspek kemandirian yang memiliki kemampuan untuk membuat keputusan secara bebas dan melakukan tindak lanjut atas keputusan yang dibuat. Steinberg (dalam Sukardi, 2013: 338) juga menjelaskan kemandirian tingkah laku adalah kemandirian dalam perilaku bebas untuk berbuat atau bertindak sendiri tanpa tergantung pada bimbingan keluarga. Kemandirian perilaku merujuk kepada kemampuan seseorang untuk melakukan aktivitas sebagai manifestasi dari berfungsinya kebebasan, dengan jelas menyangkut peraturanperaturan yang wajar mengenai perilaku dan pengambilan keputusan seseorang. Kemandirian tingkah laku seseorang dapat dilihat dari beberapa indikator, yaitu:

1) Mampu untuk membuat keputusan sendiri dan mengetahui dengan pasti kapan seharusnya meminta dan menmpertimbangan nasehat dari orang lain.

2) Mampu mempertimbangkan 
bagian-bagian alternatif dari tindakan yang dilakukan berdasarkan penilaian diri sendiri dan saran-saran dari orang lain.

3) Mampu mencapai suatu keputusan yang bebas tentang bagaimana seharusnya bertindak atau melakukan keputusan dengan penuh percaya diri.

c. Value autonomy (kemandirian nilai), yaitu aspek kebebasan untuk memaknai seperangkat prinsip tentang benar dan salah, hak dan kewajiban, apa yang penting dan apa yang kurang atau apa yang tidak penting. Steinberg (dalam Sukardi, 2013: 338) juga menjelaskan kemandirian nilai adalah kemandirian yang merujuk pada suatu pengertian mengenai kemampuan seseorang untuk mengambil keputusan-keputusan dan menetapkan pilihan yang lebih berpegang pada prinsipprinsip individual yang dimiliki daripada mengambil prinsipprinsip orang lain. Kemandirian nilai seseorang dapat dilihat dari beberapa indikator, yaitu:

1) Kemampuan individu dalam memikirkan segala sesuatu menjadi semakin abstrak, artinya berfikir tentang pentingnya memecahkan permasalahan dan mampu bersikap toleran terhadap perkembangan dalam kehidupan.

2) Keyakinan individu menjadi semakin bertambah mengakar pada prinsipprinsip umum yang memiliki beberapa basis ideologis, artinya individu memiliki keyakinan dan kepercayaan terhadap dirinya sesuai dengan arah dan tujuan yang ingin dicapai.

3) Keyakinan individu semakin baik dalam menerapkan nilai-nilai di dalam dirinya, bukan tergantung pada sistem nilai yang diterapkan oleh orang lain.

Berdasarkan pemaparan di atas dapat dipahami bahwa aspek kemandirian adalah emotional autonomy (kemandirian emosional), behavioral autonomy (kemandirian tingkah laku) dan value autonomy (kemandirian nilai).

\section{Faktor-faktor} yang Mempengaruhi Kemandirian

Menurut Suhartini (dalam Rohaedi, 2016: 20) adapun faktorfaktor yang mempengaruhi kemandirian usia lanjut ada tiga, yaitu:

a. Kondisi kesehatan

Masa tua ditandai oleh penurunan fungsi fisik, fungsi psikis, dan rentan terhadap berbagai penyakit. Kerentanan terhadap penyakit disebabkan oleh menurunnya fungsi berbagai organ tubuh. Diperlukan pelayanan kesehatan demi meningkatkan derajat kesehatan dan mutu kehidupan usia lanjut agar tercapai masa tua yang bahagia dan berguna dalam kehidupan keluarga dan masyarakat sesuai dengan keberadaannya (Suardiman, 2011: 13).

b. Kondisi sosial

Kondisi ini menunjukan kebahagian bagi usia lanjut untuk bisa mengikuti kegiatankegiatan sosial seperti keagamaan dan meningkatkan kontak sosial antar sesama. Kontak sosial ini sangat berguna bagi usia lanjut agar memiliki kesempatan untuk saling bertukar informasi, saling belajar 
dan saling bercanda. Kontak sosial akan mendatangkan perasaan senang yang tidak dapat dipenuhi bila usia lanjut dalam kesendirian (Suardiman, 2011: 12).

c. Kondisi ekonomi

Usia lanjut yang masih mandiri dalam kondisi ekonomi adalah usia lanjut yang masih bisa menyesuaikan diri dengan keadaan ekonominya saat ini. Pada umumnya kondisi ekonomi usia lanjut akan mengalami kemunduran ketika akan memasuki masa pensiun yang mengakibatkan turunnya pendapatan, hilangnya fasilitas, wewenang, kekuasaan, dan penghasilan.

Berdasarkan pemaparan di atas dapat dipahami bahwa faktorfaktor yang mempengaruhi kemandirian usia lanjut adalah kondisi kesehatan yang disebabkan oleh penurunan fungsi fisik dan psikis, kondisi sosial dan kondisi ekonomi.

\section{B. Usia Lanjut}

\section{Pengertian Usia Lanjut}

Proses menua atau aging adalah suatu proses alami pada manusia. Orang lanjut usia adalah sebutan bagi mereka yang telah memasuki usia 60 tahun keatas. Banyak istilah yang dikenal masyarakat untuk menyebut orang usia lanjut, antara lain "lansia" yang merupakan singkatan dari lanjut usia. Istilah lain adalah "manula" yang merupakan singkatan dari manusia usia lanjut, dan "usila" singkatan dari usia lanjut. Ada istilah lain yang terasa lebih enak didengar adalah wulan yang merupakan singkatan dari warga usia lanjut (Yeniar, 2012: 4)

Masa usia lanjut merupakan masa yang tidak bisa dielakan oleh siapapun khususnya yang dikaruniai umur panjang. Di Indonesia hal-hal yang terkait dengan usia lanjut diatur dalam suatu undang-undang yaitu Undang-Undang Republik Indonesia No. 13 tahun 1998 tentang Kesejahteraan Lanjut Usia, lanjut usia adalah seseorang yang telah mencapai usia 60 (enam puluh) tahun ke atas (Suardiman, 2011: 1). Berdasarkan pemaparan diatas dapat disimpulkan bahwa usia lanjut adalah seseorang yang sudah berumur 60 tahun ke atas yang sudah mengalami penurunan baik dari segi fisik maupun psikologis.

\section{Tugas Perkembangan Usia Lanjut}

Pada setiap tahap kehidupan manusia memiliki tugas perkembangan tertentu, demikian juga halnya pada usia lanjut. Sebagian tugas perkembangan usia lanjut banyak berkaitan dengan kehidupan pribadi seseorang dari pada kehidupan orang lain. Adapun tugas perkembangan usia lanjut (Hurlock, 2002: 385-386), yaitu:

1. Menyesuaikan diri dengan menurunnya kekuatan fisik dan kesehatan.

2. Menyesuaikan diri dengan masa pensiun dan berkurangnya income (penghasilan) keluarga.

3. Menyesuaikan diri dengan kematian pasangan hidup.

4. Membentuk hubungan dengan orang-orang yang seusianya.

5. Membentuk pengaturan kehidupan fisik yang memuaskan.

6. Menyesuaikan diri dengan peran sosial secara luas.

Usia lanjut diharapkan dapat menyesuaikan diri dengan menurunnya kekuatan, dan menurunnya kesehatan secara bertahap. Hal ini sering diartikan sebagai perbaikan dan perubahan 
peran yang pernah dilakukan di dalam, di luar rumah maupun di lingkungan masyarakat. Usia lanjut juga diharapkan dapat mencari kegiatan untuk mengganti tugastugas terdahulu yang menghabiskan sebagian besar waktu ketika usia lanjut masih muda. Akibat dari menurunnya tingkat kesehatan dan sosial, maka usia lanjut perlu menjadwalkan dan menyusun kembali pola hidup yang sesuai dengan keadaan saat itu, yang sangat sering berbeda dengan apa yang dilakukannya pada masa lalu (Hurlock, 2002: 380).

Berdasarkan pemaparan di atas, dapat dipahami bahwa usia lanjut dapat menyesuaikan diri dengan menurunnya kekuatan, dan menurunnya kesehatan secara bertahap, serta dapat menyusun kembali pola hidup yang sesuai.

3.

\section{yang Dihadapi Usia Lanjut}

Dalam Suardiman (2011: 9-

15) masalah yang pada umumnya dihadapi oleh usia lanjut dapat dikelompokan kedalam beberapa bagian, yaitu:

a. Masalah Ekonomi

$$
\begin{aligned}
& \text { Usia lanjut ditandai } \\
& \text { dengan menurunnya } \\
& \text { produktivitas kerja, memasuki } \\
& \text { masa pensiun atau berhentinya } \\
& \text { pekerjaan utama. Hal ini } \\
& \text { berakibat pada menurunnya } \\
& \text { pendapatan yang kemudian } \\
& \text { terkait dengan pemenuhan } \\
& \text { kebutuhan hidup sehari-hari, } \\
& \text { seperti sandang, pangan, papan, } \\
& \text { kesehatan, rekreasi dan } \\
& \text { kebutuhan sosial. Pada sebagian } \\
& \text { usia lanjut, karena kondisinya } \\
& \text { yang tidak memungkinkan, } \\
& \text { berarti masa tua tidak produktif } \\
& \text { lagi dan berkurang atau bahkan } \\
& \text { tidak adanya penghasilan. } \\
& \text { Menurut Hurlock dalam } \\
& \text { Suardiman (2011: } 11 \text { ) }
\end{aligned}
$$

mengatakan apabila pendapatan orang usia lanjut secara drastis berkurang, maka minat untuk mencari uang tidak lagi berorientasi pada apa yang ingin mereka beli dan untuk membayar simbol status yang biasa dilakukan pada kehidupan masa muda, tetapi untuk sekedar menjaga mereka agar tetap mandiri.

Secara ekonomis, penduduk usia lanjut dapat diklasifikasikan kepada tingkat ketergantungan atau kemandirian mereka. Penduduk usia lanjut dikelompokan dalam tiga kelompok, yaitu:

1) Kelompok usia lanjut yang sudah uzur, pikun (senile) yaitu mereka yang sudah tidak mampu lagi untuk memenuhi kebutuhan dasar mereka.

2)Kelompok usia lanjut yang produktif, yaitu mereka yang mampu memenuhi kebutuhan mereka sendiri dan tidak tergantung pada pihak lain.

3) Kelompok usia lanjut yang miskin, yaitu mereka yang secara relatif tidak dapat memenuhi kebutuhan mereka sendiri, seperti pekerjaan atau pendapatan yang tidak dapat menunjang kelangsungan kehidupannya.

b. Masalah Sosial

Memasuki usia lanjut ditandai dengan berkurangnya kontak sosial, baik dengan anggota keluarga, anggota masyarakat, maupun teman kerja sebagai akibat terputusnya hubungan kerja karena pensiun. Di samping itu kecenderungan meluasnya keluarga inti atau keluarga batih dari pada keluarga luas juga akan 
mengurangi kontak sosial usia lanjut.

Perubahan nilai sosial masyarakat yang mengarah pada tantanan masyarakat individualistik, berpengaruh bagi para usia lanjut yang kurang mendapat perhatian, sehingga sering tersisih dari kehidupan masyarakat dan terlantar, kurangnya kontak sosial ini menimbulkan perasaan kesepian, dan murung.

c. Masalah Kesehatan

Salah satu indikator keberhasilan pembanguan kesehatan di Indonesia adalah meningkatnya usia harapan hidup manusia Indonesia. Peningkatan jumlah penduduk usia lanjut akan diikuti dengan meningkatnya permasalahan kesehatan, seperti masalah kesehatan indera pendengaran dan penglihatan.

Kemunduran sel-sel terjadi pada usia lanjut karena proses penuaan yang berakibat pada kelemahan organ, kemunduran fisik, timbulnya berbagai macam penyakit terutama penyakit degeneratif. Hal ini akan menimbulkan masalah kesehatan, sosial dan membebani perekonomian baik pada usia lanjut maupun pemerintah, karena masingmasing penyakit memerlukan dukungan dan dana.Masa usia lanjut ditandai dnegan penurunan fungsi fisik dan rentan terhadap penyakit.

Kerentanan terhadap penyakit ini disebabkan oleh menurunnya fungsi berbagai organ tubuh, sehingga diperlukan pelayanan kesehatan terutama untuk kelainan degeneratif demi meningkatkan derajat kesehatan dan mutu kehidupan usia lanjut agar tercapai masa tua yang berbahagia dan berguna dalam keluarga dan masyarakat sesuai dengan keberadaannya.

d. Masalah Psikologis

Maslah psikologis yang dihadapi usia lanjut pada umumnya meliputi kesepian, keterasingan dari lingkungan, ketidakberdayaan, perasaan tidak berguna, kurang percaya diri, ketergantungan, ketelantaran terutama bagi usia lanjut yang miskin, post power syndrome dan sebagainya.

Kehilangan perhatian dan dukungan dari lingkungan sosial biasanya berkaitan dengan hilangnya jabatan atau kedudukan, dapat menimbulkan konflik atau keguncangan. Berbagai persoalan tersebut bersumberdari menurunnya fungsi-fungsi fisik dan psikis sebagai proses penuaan. Aspek psikologis merupakan faktor penting dalam kehidupan usia lanjut, bahkan sering lebih menonjol dari pada aspek lainnya dalam kehidupan seseorang usia lanjut.

Kebutuhan psikologis merupakan kebutuhan akan rasa aman (the safety needs), kebutuhan akan rasa memiliki dan dimiliki serta rasa akan kasih sayang (the belongingness and loves needs), kebutuhan akan aktualisasi diri (the need for self actualization). Kebutuhan akan rasa aman meliputi kebutuhan akan keselamatan, seperti keamanan, kemantapan, ketergantungan, perlindungan, bebas dari rasa takut, kecemasan, kekalutan, ketertiban dan sebagainya, dan yang intinya terbebas dari rasa takut. Sering kali menurunnya 
atau tiadanya pekerjaan serta penghasilan menimbulkan ketakutan.

Adapun dalam Hurlock (2002: 387) menjelaskan beberapa masalah umum yang unik dihadapi oleh usia lanjut, yaitu:

a. Keadaan fisik lemah dan tidak berdaya sehingga harus bergantung dengan orang lain.

b. Siklus ekonominya sangat terancam, sehingga cukup beralasan untuk melakukan berbagai perubahan besar dalam pola hidupnya.

c. Menentukan kondisi hidup yang sesuai dengan perubahan status ekonomi dan kondisi fisik.

d. Mencari teman baru untuk menggantikan suami atau istri yang telah meninggal ataupun cacat.

e. Mengembangkan kegiatan baru untuk mengisi waktu luang yang semakin bertambah.

f. Belajar untuk memperlakukan anak yang sudah besar sebagai orang dewasa.

g. Mulai merasakan kebahagian dari kegiatan yang sesuai untuk orang berusia lanjut dan memiliki kemauan untuk mengganti kegiatan lama yang berat dengan kegiatan yang lebih cocok.

h. Menjadi korban atau dimanfaatkan oleh para penjual obat, buaya darat dan kriminalitas karena tidak sanggup lagi untuk mempertahankan diri.

Berdasarkan pemaparan di atas dapat peneliti simpulkan bahwa masalah yang dihadapi usia lanjut berupa yaitu: masalah ekonomi yang ditandai dengan menurunnya produtivitas kerja dalam memasuki masa pensiun atau berhentinya pekerjaan utama pada usia lanjut. Masalah sosial pada usia lanjut ditandai dengan berkurangnya kontak sosial baik dengan anggota keluarga, anggota masyarakat, maupun teman kerja sebagai akibat putusnya hubungan kerja karena pensiun. Masalah kesehatan pada usia lanjut ditandai dengan penurunan fisik dan rentannya penyakit pada usia lanjut, dan msalah psikologis yang mana ditandai dengan masalah kesepian, keterasingan dari lingkungan, ketidakberdayaan, perasaan tidak berguna, kurangnya rasa percaya diri, ketergantungan dan keterlantaran bagi usia lanjut yang miskin.

\section{Perubahan Fisik pada Usia Lanjut}

Dalam Suardiman (2011: 3646) perubahan fisik yang dialami oleh usia lanjut dibagi menjadi beberapa perubahan, yaitu:

a. Perubahan Fisik

Usia lanjut adalah suatu proses alami yang ditandai dengan penurunan fisik. Semua makhluk hidup di dunia memilki siklus kehidupan yang diawali dari proses kelahiran, kemudian tumbuh menjadi dewasa dan berkembang biak, selanjutnya menjadi semakin tua, menderita berbagai penyakit dan ketidakmampuan dan akhirnya meninggal dunia.

Proses menjadi usia lanjut disebabkan oelh faktor biologis yang terjadi atas 3 fase yaitu, fase progresif, fase stabil, dan fase regresif. Dalam fase regresif, mekanisme lebih kearah kemunduran yang dialami oleh sel, komponen kecil dari tubuh manusia. Usia biologis ini sering juga dibedakan atas fase pertumbuhan, fase pematangan, dan fase penurunan.

Sel-sel menurun fungsinya karena telah lama 
berfungsi, sehingga proses kemunduran lebih dominan dibandingkan dengan terjadinya proses pemulihan. Penurunan pada aspek fisik meliputi perubahan pada kerangka tubuh, tulang menjadi keras, dan mudah patah. Sistem saraf pusat berkurang yang mengakibatkan menurunnya kecepatan belajar dan mengingat, sehingga usia lanjut mudah lupa.

Kulit kehilangan elastisnya, kering dan keriput sehingga tidak tahan panas dan dingin, organ alat indera mengalami penurunan fungsi sehingga menurun dalam sensitifitas dan efisiensinya. Organ reproduksi menurun potensinya dalam kecepatan yang tidak sama antara pria dan wanita, namun dorongan seksual belum tentu menurun. Kecepatan motorik menurun, sehingga kecepatan reaksi dan koordinasi gerak kurang baik dan terkesan lamban. Menuanya organ tubuh berakibat usia lanjut mudah atau rentan terhadap penyakit-penyakit degeneratif.

Perubahan fisik pada usia lanjut lebih pada perubahan fungsi biologis. Usia lanjut adalah suatu proses yang berangsur-angsur yang dimulai sejak awal kehidupan. Fungsinpuncak maksimum biologis dicapai seseorang pada usia 25-30 tahun, sesudahnya akan terjadi penurunan. Secara berangsur-angsur dalam hal kekuatan otot, kelenturan, efisiensi sirkulasi, kecepatan respon, ketajaman indera, dan fungsi-fungsi lainnya.

Menurut Hurlock (2002: 386-390) yang termasuk kedalam perubahan fisik adalah perubahan penampilan. Adapun perubahan-perubahan umum dalam penampilan selama usia lanjut, yaitu:

1) Perubahan pada daerah kepala

Perubahan pada daerah kepala ini terlihat pada hidung yang menjulur lemas, bentuk mulut berubah akibat hilangnya gigi atau karena memakai gigi palsu, perubahan pada mata yang kelihatan memudar, tak bercahaya dan sering kali mengeluarkan cairan.

Kulit mulai tampak kering, berkerut, berbintik hitam bahkan banyaknya tumbuh tahilalat. Rambut menipis, berubah menjadi putih, dan kaku, serta tumbuhnya rambut dibagian hidung, telinga dan pada alis.

2) Perubahan pada daerah tubuh Perubahan pada daerah tubuh terlihat pada bahu yang terlihat membungkuk dan tampak mengecil. Perut yang sudah mulai besar dan buncit, pinggul tampak mengendor dan lebih lebar dibandingkan dengan waktu muda. Garis pinggang melebar, menjadikan badan tampak seperti terisap. Bahkan tampak pada payudara bagi wanita menjadi kendor dan melorot.

3) Perubahan pada daerah persendian

Perubahan daerah persendian terlihat pada pangkal tangan dan kaki yang menjadi kendor, terasa berat, sedangkan ujung tangan sudah tampak mengerut, kuku tangan dan 
kaki juga tampak menebal, mengeras dan mengapur.

b. Penurunan Berbagai Fungsi Indrawi

Penurunan fungsi indrawi pada usia lanjut meliputi, penglihatan, pendengaran, pengecapan, pembauan dan rasa (sakit). Penurunan berlangsung secara berangsur-angsur, dan dimulai sejak usia pertengahan.

1) Penglihatan

Berk menyatakan
bahwa
penglihatan dimulai saat

memasuki masa dewasa

awal atau masa dewasa

akhir. Penurunan fungsi

penglihatan, terutama pada

objek dengan tingkat

penerangan yang rendah, juga menurunnya

sesitivitas terhadap warna.

2) Pendengaran

Kemampuan

pendengaran yang

berkurang sebagai akibat dari berhentinya pertumbuhan saraf, antara usia 45 sampai 65 tahun. Manusia mulai mengalami penurunan pendengaran secara berangsur-angsur. Meskipun sementara orang kehilangan pendengaran terkait dengan keturunan atau genetika namun menurunnya pendengaran yang berhubungan dengan umur seseorang sering disebut dengan presbycusi.

3) Kulit

Kulit terdiri atas tiga bagian, yaitu: epidemis atau lapisan paling luar yang melindungi, dimana dihasilkan secara ajeg selsel kulit baru. Dermis atau lapisan tengah terdiri atas jaringan penghubung yang lentur dan kembali lagi yang membuat kulit flesibel, dan hypodermis jaringan lemak yang paling dalam yang menambah garis lunak dan terbalik dari kulit.

aSemakin tinggi usia seseorang, jaringan epidermis menjadi kurang kelekatannya dengan dermis, serabut dalam dermis menjadi tipis, dan lemak dalam hypodermis berkurang, sehingga kulit menjadi berkeriput dan tidak halus lagi.

4) Perasa

Fungsi alat perasa
juga menurun sebagai akibat dari berhentinya pertumbuhan tunas perasa yang terletak di lidah dan di permukaan bagian dalam pipi. Berhentinya saraf perasa ini terus menerus sejalan dengan bertambahnya usia. Kemampuan penciuman juga menurun. Indera peraba mengalami penurunan kepekaan karena kulit semakin kering dan keras. Ketahan terhadap rasa sakit juga menurun terutama dibagian dahi dan tangan, sedangkan pada kaki tidak seburuk dari kedua organ tersebut.

5) Keropos Tulang

Ketika terjadi akumulasi sel-sel baru pada jaringan luar, tulang membesar, tetapi kandungan mineralnya menurun sehingga menjadi keropos. 
6) Membau dan Mencecap

Kepekaan atas rasa asam lebih besar dibandingkan dengan rasa manis dan asin. Makan buah yang agak asam sudah tidak tertarik lagi meski ketika muda dulu penggemar rujak yang terdiri dari buah-buah yang asam.

7) Aktivitas Seksual dan Fungsi Reproduksi

Produksi hormon seks pada pria dan wanita menurun dengan bertambahnya usia, selain itu produksi hormon pada pria dan wanita yang menurun juga dipengaruhi oleh monopause pada wanita dan andropause pada pria.

Berdasarkan pemaparan di atas dapat diketahui bahwa perubahan fisik pada usia lanjut ditandai dengan penurunan fisik dan penurunan indrawi, penurunan fisik seperti kulit kehilangan elastisnya, tulang mengeras dan mudah patah, sistem saraf berkurang yang mengakibatkan menurunnya kecepatan belajar, mengingat sehingga para usia lanjut mudah lupa, dan perubahan umum dalam penampilan lansia seperti daerah kepala, daerah tubuh, dan daerah persendian, sedangkan penurunan indrawi ditandai dengan, penglihatan, pendengaran, kulit, perasa, keropos tulang, membau dan mencecap, serta aktivitas seksual dan fungsi reproduksi.

\section{METODE PENELITIAN}

Metode yang digunakan dalam penelitian ini adalah metode penelitian kualitatif dengan model penelitian studi kasus. Subjek penelitian terdiri dari 1 orang subjek primer dan 2 orang subjek sekunder. Teknik pengumpulan data dalam penelitian ini adalah observasi, wawancara dan dokumentasi. Analisis data yang digunakan dalam penelitian ini adalah analisis model Miles \& Huberman.

\section{HASIL PENELITIAN}

Hasil penelitian ini sesuai dengan batasan penelitian yang ingin diketahui. Pertama,dapat diketahui bahwa $\mathrm{R}$ merupakan usia lanjut yang memiliki kemandirian di dalam dirinya, pada umumnya $\mathrm{R}$ memenuhi semua indikator yang ada di dalam aspek kemandirian emosional. $\mathrm{R}$ dalam melakukan kegiatan sehari-hari tidak mengeluh kepada orang lain mengenai kegiatan yang dilakukannya. Ketika $\mathrm{R}$ merasa sedih dan merasakan kekecewaan, ia tidak menceritakannya kepada orang lain, hanya $\mathrm{R}$ menceritakannya kepada keluarganya saja.

Kedua, dapat diketahui bahwa $\mathrm{R}$ hanya memenuhi beberapa indikator dari aspek kemandirian tingkah laku, dalam mengambil suatu keputusan $\mathrm{R}$ mempertimbangkan terlebih dahulu apa yang akan dilakukannya, apakah keputusan diambil baik atau tidak bagi dirinya. Ketika membuat keputusan $\mathrm{R}$ tidak pernah ragu dengan keputusan yang dibuatnya, seperti dalam mengambil keputusan kalau $\mathrm{R}$ akan tetap bekerja atau berjualan di Pasar walaupun anak-anaknya sudah melarang, karena bagi $\mathrm{R}$ berjualan dengan mengikuti banyak kegiatan bisa membuat ia merasa bahagia.

Ketiga, dapat diketahui bahwa $\mathrm{R}$ memenuhi semua indikator yang ada dalam aspek kemandirian nilai, dalam memecahkan suatu masalah yang dihadapi, $\mathrm{R}$ tidak langsung menyelesaikannya sendiri, tetapi $\mathrm{R}$ mufakat terlebih dahulu dengan suami dan anaknya bagaimana cara menyelesaikan masalah tersebut. $\mathrm{R}$ memiliki harapan untuk berhasil, dengan cara menerapka keyakinan bahwa ia akan berhasil dengan cara selalu berusaha. 


\section{KESIMPULAN}

Berdasarkan hasil penelitian dan pembahasan tentang kemandririan pada usia lanjut di Dusun Koto Malintang Jorong Baso Kenagarian Tabek Panjang Kabupaten Agam, maka sesuai dengan fokus penelitian, penulis dapat menarik kesimpulan bahwa:

1. Kemandirian emosional pada usia lanjut di Dusun Koto Malintang Jorong Baso Kenagarian Tabek Panjang Kabupaten Agam, dapat dilihat bahwa dalam melakukan kegiatan sehari-hari subjek tidak mengeluh kepada orang lain mengenai kegiatan yang dilakukannya. Ketika subjek merasa sedih dan merasakan kekecewaan, ia tidak menceritakannya kepada orang lain, subjek hanya menceritakannya kepada keluarganya saja.

2. Kemandirian tingkah laku pada usia lanjut di Dusun Koto Malintang Jorong Baso Kenagarian Tabek Panjang Kabupaten Agam, dapat dilihat bahwa dalam mengambil suatu keputusan subjek mempertimbangkan terlebih dahulu apa yang akan dilakukannya, apakah keputusan diambil baik atau tidak bagi dirinya. Ketika membuat keputusan subjek tidak pernah ragu dengan keputusan yang dibuatnya, seperti dalam mengambil keputusan kalau subjek akan tetap bekerja atau berjualan di pasar walaupun anakanaknya sudah melarang, karena bagi subjek berjualan dengan mengikuti banyak kegiatan bisa membuat ia merasa bahagia.

3. Kemandirian tingkah laku pada usia lanjut di Dusun Koto Malintang Jorong Baso Kenagarian Tabek Panjang Kabupaten Agam, dapat dilihat bahwa dalam memecahkan suatu masalah yang dihadapi, subjek tidak langsung menyelesaikannya sendiri, tetapi subjek mufakat terlebih dahulu dengan suami dan anaknya bagaimana cara menyelesaikan masalah tersebut. Subjek memiliki harapan untuk berhasil, dengan cara menerapka keyakinan bahwa ia akan berhasil dengan cara selalu berusaha.

Adapun faktor yang mempengaruhi usia lanjut ini memiliki kemandirian pada dirinya yang terlihat dari kemandirian emosinal, kemandirian tingkah laku, dan kemandirian nilai adalahfaktor kesehatan dimana usia lanjut ini memiliki kesehatan fisik dan kesehatan psikis yang baik, dengan kesehatanya yang baik dapat membuat usia lanjut untuk tetap mandiri dalam melakukan sesuatu, faktor sosial dimana usia lanjut ini mampu bersosialisasi dengan lingkungan sekitar, memiliki hubungan yang baik, dan memiliki sikap tolong menolong antar sesama, faktor ekonomi dimana usia lanjut ini memiliki penghasilan yang sudah bisa dibilang cukup untuk kehidupannya seharihari, dan faktor keagamaan dimana usia lanjut ini mengikuti kegiatan mengaji ke setiap-tiap tempat yang berbeda, dan selalu bersedekah.

\section{DAFTAR PUSTAKA}

Arumsari, A, dkk. (2016). Perbedaan Tingkat Kemandirian Remaja Ditinjau dari Pola Asuh Orangtua pada Siswa

Kelas IX SMP Islam Al-Abidin Surakarta. Jurnal Ilmiah Psikologi Cadrajiwa. Vol 5. No 1. Juni 2016.

Chaplin, J. P. (2005). Kamus Lengkap Psikologi. Jakarta: Raja Grafindo Persada.

Desmita. (2010). Psikologi Perkembangan Peserta Didik. Bandung: Remaja Rosdakarya.

Gunawan, Imam. (2014). Metode Penelitian Kualitatif.: Teori dan Praktik. Jakarta: Bumi Aksara.

Herdiansyah, H. (2010). Metodologi Penelitian Kualitatif. Jakarta: salemba Humanika.

Hosnan, M. (2016). Psikologi Perkembangan Peserta Didik. Kiat Sukses Pendidikan Anak dalam Era Modren. Ghalia Indonesia: Bogor. 
Hurlock, E. B. (2002). Psikologi Perkembangan Suatu Pendekatan Sepanjang Rentang Kehidupan Edisi Kelima. Jakarta: Erlangga.

Inayah, N. V. (2017). Gamabaran tentang Kemandirian Lansia dalam Pemenuhan Aktivitas Sehari-hari di Posbindu Desa Sindajawa Kabupaten Cirebon. Skripsi. Program Studi Ilmu Keperawatan Fakultas Kedokteran dan Ilmu Kesehatan Universitas Syarih Hidayatullah Jakarta.

Indriani, Yeniar. (2015). Gerontologi\& Progeria. Yogyakarta: Pustaka Pelajar.

Kurniati, S. (2013). Kemandirian Lansia Di Panti Sosial Tresna Werdha Abdi Binjai. Skripsi. Fakultas Psikologi Universitas Sumatera Utara.

Nauli, F, A, dkk. (2014). Hubungan Tingkat Depresi Dengan Tingkat Kemandirian Dalam Aktifitas Sehari-Hari Pada Lansia di Wilayah Kerja Puskesmas Tembilan Hulu. Jurnal Keperawatan Soedirman (The Soedirman Journal of Nursing) Volume 9, No.2. 2014.

Papalia, Diane E, et al. 2011. Human Development (Psikologi Perkembangan) Edisi KeSembilan. Jakarta: Kencana.

Rohaedi, S. Putri, T, S \& Karimah, D, A. (2016). Tingkat Kemandirian Lansia Dalam Activities Daily Living Di Panti Sosial Tresna Werdha Senja Rawi. Jurnal Pendidikan Keperawatan Indonesia. Vol. 2. No. 1. Juli. 2016.

M. Quraish Shihab. (2002). Tafsir AlMisbah: pesan, kesan dan keserasian Al-Qur'an. Jakarta: Lentera Hati.

Suardiman, P, S. (2011). Psikologi Usia Lanjut. Yogyakarta: Gadjah Mada University Press.
Sugiyono. (2010). Metode Penelitian Kuantitatif dan Kualitatif dan $R \& D$. Bandung: Alfabeta.

Sukardi, T. (2013). Faktor-faktor yang Mempengaruhi Kemandirian untuk Berwirausaha pada Siswa SMP. Jurnal Pendidikan Vokasi. Vol 3. Nomor 3. November. 2013. Universitas Negeri Yogyakarta.

Wulandari, R. (2014). Gambaran Tingkat Kemandirian Lansia dalam Pemenuhan ADL (Activity Daily Living). Jurnal Ners dan Kebidanan Volume 1 No 2, Juli 2014.

Zakariya, A. (2009). Faktor-faktor yang Berhubungan Dengan Kemandirian Pada Lanjut Usia Di Panti Sosial Tresna Werdha (PSTW) Budi Mulia Margaguna Jakarta Selatan Tahun 2009. Skripsi. Tidak Diterbitkan. Fakultas Kedokteran dan Ilmu Kesehatan Universitas Islam Negeri Syarif Hidayatullah jakarta. 